Springer Proceedings in Business and Economics

Vicky Katsoni Editor

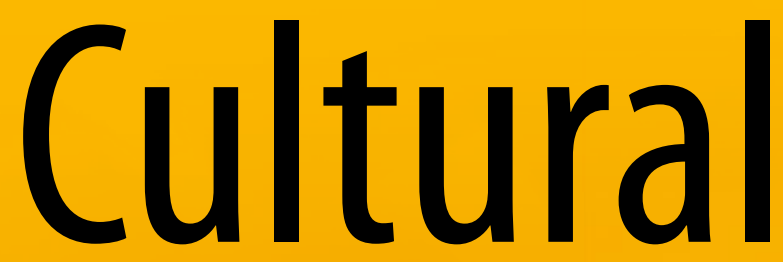

Tourism in

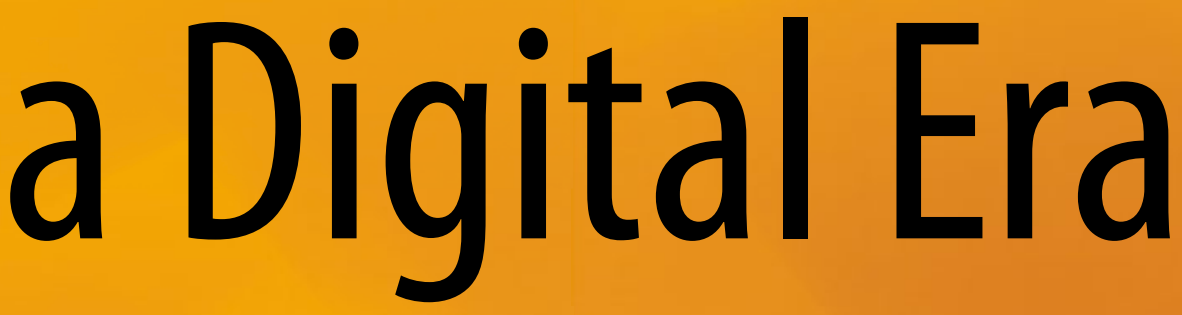

First International Conference IACuDiT, Athens, 2014

Springer 
Springer Proceedings in Business and Economics 
More information about this series at

http://www.springer.com/series/11960 
Vicky Katsoni

Editor

\section{Cultural Tourism in \\ a Digital Era}

First International Conference IACuDiT, Athens, 2014

第 Springer 


\author{
Editor \\ Vicky Katsoni \\ Technological Educational Institute \\ Athens, Greece
}

ISSN 2198-7246

ISSN 2198-7254 (electronic)

Springer Proceedings in Business and Economics

ISBN 978-3-319-15858-7 ISBN 978-3-319-15859-4 (eBook)

DOI 10.1007/978-3-319-15859-4

Library of Congress Control Number: 2015936693

Springer Cham Heidelberg New York Dordrecht London

(C) Springer International Publishing Switzerland 2015

This work is subject to copyright. All rights are reserved by the Publisher, whether the whole or part of the material is concerned, specifically the rights of translation, reprinting, reuse of illustrations, recitation, broadcasting, reproduction on microfilms or in any other physical way, and transmission or information storage and retrieval, electronic adaptation, computer software, or by similar or dissimilar methodology now known or hereafter developed.

The use of general descriptive names, registered names, trademarks, service marks, etc. in this publication does not imply, even in the absence of a specific statement, that such names are exempt from the relevant protective laws and regulations and therefore free for general use.

The publisher, the authors and the editors are safe to assume that the advice and information in this book are believed to be true and accurate at the date of publication. Neither the publisher nor the authors or the editors give a warranty, express or implied, with respect to the material contained herein or for any errors or omissions that may have been made.

Printed on acid-free paper

Springer International Publishing AG Switzerland is part of Springer Science+Business Media (www.springer.com) 


\section{Contents}

\section{Part I Consumers' View on Today's Tourism Industry}

The Views of Greek Mountain Travelers on Mountain Tourism During Summertime: A Questionnaire Web-Based Analysis . . . . . . . . . 3 Natali Dologlou and Vaios Kotsios

Preferences and Behaviors of the Elder People Resting in Valuable Natural Areas . . . . . . . . . . . . . . . . . . . .

Jan Zawadka

Interrelationships of Service Quality, Customer Satisfaction, Corporate Image and Customer Loyalty of Malaysian Hotel Industry . . . . . . . . Boon Liat Cheng and Zabid Abdul Rashid

Egyptian Tourism with the Expected Water Scarcity Crisis . . . . . . . .

Sameh A. Refaat

The Concept of Classification of Tourist Motivation Factors . . . . . . .

L.A. Koziol and R.W. Pyrek

\section{Part II Cultural Tourism Today}

Art in the Globalised Era: A Disembodied Journey with Traces in the Past . . . . . . . . . . . . . . . . . . . . . . .

Spiros Polimeris and Christine Calfoglou

Russian Artistic Gymnastics as a Sports Tourism Product: Some

Observations and a Research Agenda . .

Elizabeth Booth, Jithendran Kokkranikal, and Olga Burukina

Greek Museums on the Web

V. Vrana, D.M. Nerantzaki, and D. Paschaloudis 
Rose and Olive Heritage in Bulgaria and Greece: A Comparative Study . . . . . . . . . . . . . . . . . . . . . . . . . 111

Vesselin Loulanski and Tolina Loulanski

Promotion of Cultural Heritage Tourism in Chokhatauri District in Georgia . . . . . . . . . . . . . . . . . . . . . . . . . . 113

Eka Devidze and Lali Gigauri

Application of a Cultural Landscape Tourism Marketing Management

Approach in a Mountainous Area . . . . . . . . . . . . . . . . . . . . . 121

Vicky Katsoni

Approaching the Monuments of the 'Other': A Model for Their

Presentation .

Vasiliki Mitropoulou

Pilgrimage in Georgia .

Tinatin Kublashvili and Nato Kublashvili

Wandering as the Determinant of Identity and Difference in Ancient Greek Literature: The Paradigm of Herodotus and Pausanias . . . . . . . 159 Pitropou Ekaterini

Motivations and Experiences of Museum Visitors: The Case of the

Imperial War Museum, United Kingdom

Raymond Powell and Jithendran Kokkranikal

Part III Heading Towards a Digital Model of Tourism

Game-Based Learning and Lifelong Learning for Tourist Operators . . . 185

R. Pace and A. Dipace

The Effectiveness and Impact of Intellectual Property Rights:

The Case of Digital Content Industry of Taiwan . . . . . . . . . . . . . . . 201

Chih-cheng Lo

The "Clinical Risk" of a Research Project: Communication

Processes

Daniela Dato

Crowdsourced Heritage Tourism Open-Data, Small-Data and e-Participatory Practices as Innovative Tools in Alps Cultural Heritage Topic: Information Technology and e-Tourism . . . . . . . . . . 229 Daniele Villa

Digital Divide and Its Potential Impact on Cultural Tourism . . . . . . . 231 Christian Maurer 
Reflections of Destinations on Social Media

Gökçe Özdemir and Duygu Çelebi

An ICT-Based Competence Framework to Facilitate Intercultural

Competence Continuous Professional Development

Simon Caruana

Web 2.0 Enhancing Role in Heritage Interpretation Based on

Constructivist Learning Theories

Vlassi Eirini

Xperience the CITY: The City of Destination as an Integrator and

Its Role in Co-creating Travel Experiences

Evangelia G. Dougali, Sicco C. Santema,

and W.W.A. Beelaerts van Blokland

Part IV Tourism Product from an Alternative Perspective

Civilized Observers in a Backward Land: British Travellers in Greece,

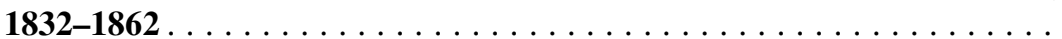

Pandeleimon Hionidis

Agritourism as a Form of Recreation for Students .

Agata Balińska

The Effect of Visiting Friends and Relatives on Expatriates' Destination

Knowledge: Abstract .

Chris Dutt, Ivan Ninov, and Donna Haas

Visitor Attraction Management: Is There Space for New Thinking Despite the Crisis? The Cases of Buckingham Palace and the Museum of Acropolis .

G. Aspridis, L. Sdrolias, Th. Kimeris, D. Kyriakou, and I. Grigoriou

Tourism Business Sector Stance in Front of a Sport Tourism

Development: Focusing on Crete . . . . . . . . . . . . . . . . . . . . . . . . . . . . 349

Leonidas Gaitanakis, Ourania Vrondou, Thanos Kriemadis, and Giannis Douvis

Planning the Sustainable Tourist Development of Zakynthos Island:

A Methodological Framework .

E. Kapsaski, M. Panagiotopoulou, and A. Stratigea

Sentiment Analysis of Hotel Reviews in Greek: A Comparison of Unigram Features .

George Markopoulos, George Mikros, Anastasia Iliadi, and Michalis Liontos

Development of Tourism in Apulia Region and Training of Tour

Operators .

Isabella Loiodice 
Natural and Cultural Resources as a 'Vehicle' for Paving Alternative Local Tourist Development Paths: A Participatory Methodological Framework.

M. Panagiotopoulou and A. Stratigea

Feasibility Study of Creating Audio Tourism with Emphasis on Urban Sounds . .

Mohammad Hossein Tamjidi and Zeinab Lotfalikhani 


\section{Part III \\ Heading Towards a Digital Model of Tourism}




\title{
Game-Based Learning and Lifelong Learning for Tourist Operators
}

\author{
R. Pace and A. Dipace
}

The paragraphs "Game Based Lifelong Learning for Tourist Operators"; "The gamification actions in the Sonetto's community" were written by Anna Dipace. The paragraphs "Introduction"; "Sonetto: an environment for learning"; "Further directions" were written by Rosaria Pace.

\begin{abstract}
Today's workplace challenges are based on the belief that the group can face current challenges better using collaboration than any individual can by yourself. This belief has prompted social solutions, such as communities of practice or knowledge and social peer-learning.

Learning by playing a game is a very old method that is still applied in various contexts. Mainly in social-learning activities, the learner's motivation is crucial to program success. Games are fun and immersive by nature. By using games in lifelong learning contexts, it is possible to deliver continuous high attention and engagement for substantial learning.
\end{abstract}

Keywords Social media $\bullet$ Emerging technologies and e-tourism

\section{Introduction}

The So.Net.T.O. Project (Social Network for Tourism Operators) has represented a great chance to dialogue and to build a partnership among three research groups: Technological Educational Institution (T.E.I) of Epirus, the University of Foggia and the University of Salento. Each research unit has brought its own contribution

\footnotetext{
R. Pace

Department of Humanities - ERID Lab, University of Foggia, Via Arpi, 155, 71121 Foggia, Italy

e-mail: rosaria.pace@unifg.it
}

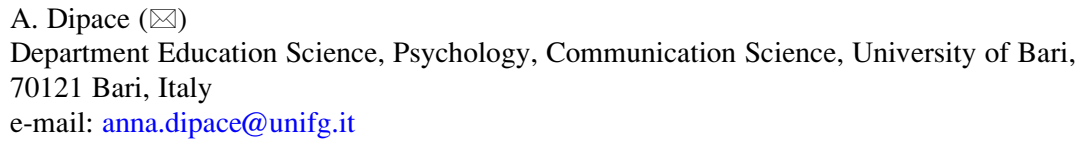


in terms of planning and developing a digital learning environment for tourism operators. They have also tried to find methods and tools to improve the local growth and to share the legal aspects of the transnational tourism regulations.

The main goal of the research and of the digital environment development is to value the social networking and the tourism operator's informal net, in order to build a virtuous communication system, to share specialized information and to value the local enterprises.

The planning of the Sonetto environment has been thought according to concept of social networking of Danah Boyd and Nicole B. Ellison (2008) who state that “"social networking' emphasizes relationship initiation, often between strangers"(p. 211). This is in contrast with what usually happens on the social networks that is "to be in contact with people who are already a part of their extended social network" (Ellison, 2008) and not to just meet new people. The Sonetto Project aims to be a connecting link for those who operate in the tourism industry, food services, accommodations, local promotions' operators and international tourism legislation, in order to permit a mutual and an interdisciplinary growth. Embracing the statements of Colin Gray and Keith Smyth (2012), we could say that

Due to their distributed online nature and asynchronous communication features, online networking tools have become central to supporting the activity of formal and informal learning communities and can be very effective in allowing for what Lave and Wenger term the process of legitimate peripheral participation where by new members can observe and learn vicariously before becoming an increasingly active contributor as their knowledge and confidence grows. Online social networking tools also offer clear advantages for the sharing of expertise and ideas amongst busy, time-limited professionals (Gray \& Smyth, 2012, p. 60).

This important potentiality and the social networking affordances above mentioned have been the core of the resources planning and of the Sonetto environment itself.

\section{Game Based Lifelong Learning for Tourist Operators}

From the point of view of the lifelong learning and of the society of knowledge, the rigid idea of a tripartite learning born in the 1990s, divided in formal, non-formal and informal ${ }^{1}$ should be necessarily rethought.

\footnotetext{
${ }^{1}$ Acquiring the several claims about the three different classifications of learning from the Memorandum about education and lifelong learning since 2000 until today, we could synthesize in this way: "formal learning is a structured and organized learning for educational purposes. It takes place at school or similar educational structures; it is voluntary from the point of view of the learner and provides for certificates." On the other hand, "the non-formal learning can be defined as a semi-structured learning with planned activities in relation to an organized context; it takes place outside the school and similar structures; it is voluntary from the point of view of the learner
} 
As Giovanni Bonaiuti asserts (2006, p.49) "none can '...' deny how relevant, within the knowledge of the young generations, the outside-school and the entire experiential production obtained from the media and other agents is." The professional contexts, of course, give more value to the concept of informal learning. According to Baert, De Witte, and Sterck (2000), informal learning is an important determinant for the professionalization of employees and organizations. Learning is particularly meaningful when it is part of valued relationships, shared practice, culture, and identity. By contrast, many researches in settings where formal education has not been prevalent (Greenfield, 2004; Rogoff, 2003; Scribner \& Cole, 1973), they add value to all learning that people develop within the contexts of work, in social interactions and during the social and cultural processes of the community. The results from these researches on lifelong learning, investigates how adults reconceptualise and reflect on earlier educational experience and practice. The knowledge and skills that people obtain in these settings have an encouraging value for participants since they are related to practices and relationships in which learning does not represent the primary aim for engagement. In other words, learning is relational and tied to shared purpose and activity. "This cross-cultural work on informal learning has helped us recognize learning that happens within the flow of everyday social life, work, and other kinds of purposeful activity" (Ito et al., 2013).

Because of the unexpected changes of the finance, markets and technologies, the contemporary scenario is very complex and the small and medium-sized business have to demonstrate the ability to understand the present to anticipate new solutions. Eva Kyndt et al. (2009, pp. 369-370), referring to Eraut (1994), states that "workplace learning is more efficient than formal training when it comes to learning job-related skills and obtaining knowledge, because these specific skills and knowledge are less appreciated in formal education and the learners frequently lack the necessary insight to put theory into practice".

The following table, proposed by Kurt Squire and Nathan Patterson (2010), synthesizes and shows clearly the main features and differences between formal and non-formal learning context (Table 1).

The Sonetto Project belongs to the lifelong learning actions that are aimed to promote enterprising spirit and business in an innovative and digital learning environment. Particularly, the lifelong learning concept, meant as education that protracts all lifelong beyond the space-time boundaries imposed by the educational system, has been established by organizations such as UNESCO (United Nations Educational, Scientific and Cultural Organization), l'OECD (Organization for Economic Cooperation and Development) and the Council of Europe and it represents an example of the changed relation between life and learning. In this new point of view are the life's events that shape the time, the space and the

and usually does not provide for certificates". In the end, "the informal learning" takes place during the everyday actions connected with work, family and free-time; it is not voluntary, it's unstructured and unorganized for educational purposes and, of course, it does not provide for certificates" (Marconi, 2008, pp. 51-52). 
Table 1 Comparison of attributes of informal educational settings (Squire \& Patterson, 2010, p.10)

\begin{tabular}{l|l|l}
\hline Dimensions & Informal settings & Formal settings \\
\hline Time structure & Flexible & Rigid \\
\hline Participation & Voluntary & Compulsory \\
\hline Educational goals & Emergent & Largely defined \\
\hline Age grouping & Flexible & Largely age-divided \\
\hline Degree of authenticity & Potentially high & Generally low \\
\hline Uniformity of outcomes & Little & High \\
\hline Disciplinary boundaries & Flexible & Fixed \\
\hline & &
\end{tabular}

development of new knowledge and competence. In May 2009, the Council of the European Union adopted a strategic plan for the European cooperation for education and formation (ET 2020). The strategic plan sets the goals of the Education and Training 2010 Work Programme and reconsidered strategy of Lisbon (European Commission, 2005) whose aim is to give to Europe an economy based on the most competitive and dynamic knowledge in the world. Education and training have a crucial role, and efficient investments on human capital are needed to realize a knowledge-based growth and at the same time to promote personal fulfillment, social cohesion and active citizenship.

The growing need to incentive lifelong learning processes, free from structured space-time boundaries, makes easier the building of an on-line community that gives chances to the professionals to become responsible of their own learning (self-regulated learning) and to control the changes of their cultural and professional growth. As usually, formal education is perceived by most as an unlikeable activity, the dynamic platform of Sonetto and its advanced management system allowed participants to receive high and immediate values during the project, through informal education strategies.

Jay Cross in his book, Informal Learning: Rediscovering the Natural Pathways that Inspire Innovation and Performance (2007), claims that the workers learn much more in the coffee room than in formal educational contexts. Using the same metaphor, the Sonetto integrated environment aims to act exactly like the coffee room suggested by Jay Cross.

Through these informal education strategies, it has been possible to plan formative actions based on game-based learning with a reference to the most recent literature on gamification.

According with Sebastian Kelle, Sigurðarson, Westera, and Specht (2011, p.338)

the main objective of a game-based learning approach for lifelong learning is thus the sustenance of this motivation and helping learners over the hurdle of getting truly comfortable with the overall learning process they have engaged upon. While this may seem like a noble goal, the challenge is far from trivial.

The Game-Based Learning methodology plans actions and didactic resources that consider the possibility to use video game with educational goals. The video 
games, for example, become disposals that allow and support a learning process. Given the engaging nature of digital games, many people think that they can increase the motivation of the players of all age. The digital games offer stimulating experiences that help the inner satisfaction of the players keeping them motivated and concentrated. In a video game, amusement and learning are strongly connected. In particular, the learning is more substantial when the player feels strong emotions and amuses himself. The game-dynamics have to facilitate an active engagement that leads the player to solve difficult but not impossible problems. Moreover, the game helps the feedback processes that encourage the obviousness of the realized progresses, having an effect on motivation and commitment. Therefore, video games act on the development of competences through the repetition of some experiences and the solution of a problem through the problem-solving and learning by doing methodology. According with Debbe Thompson et al. (2010, p. 2) "video games offer potential behaviour change channels by embedding functional knowledge and change procedures such as goal setting, modelling, and skill development activities into a personally meaningful, entertaining, and immersive game environment".

Moreover, studies and researches conducted by James Paul Gee (2004) show how video games hold up learning and social interaction create an environment in which their actions and decisions have an effect, promote creative problem solving, and improve understanding by promoting systems thinking or helping the player see the big picture.

As Kurt Squire (2008) states,

Game-based learning can be understood as a particular kind of designed experience, where players participate in ideological worlds, worlds designed to support a particular kind of reactions, feelings, emotions, and at times, thoughts and identities, which game-based learning designers are leveraging for education and training.

\section{Sonetto: An Environment for Learning}

The features that characterize the Sonetto environment from other social travel and professional communities can be summarized in the following points:

\section{Shared Writing Process: Tourism Operators as Storyteller}

The multimedia resources are produced in collaboration with operators who become the actors of the narration, the designers of territory's tale, the authors of texts to share on-line; so that the social network, as an articulated and synergic digital work, belong to "wider textual universe' of online communication in which all the email exchanges, i'm chats, bulletin boards and so on feature" (Merchant, 2012, p. 8).

\section{Integrated Environment: The Blending of Reach and Different Resources}

From a functional point of view, the environment configures itself as an integrated resource that allows activities of different nature and supports the users in actions of 
Table 2 An overview of Sonetto platform sections and resources

\begin{tabular}{l|l|l}
\hline Areas & Resources & Activities \\
\hline $\begin{array}{l}\text { Communication } \\
\text { process }\end{array}$ & $\begin{array}{l}\text { - Chat, } \\
\text { - Forum } \\
\text { - Personal wall } \\
\text { - Community }\end{array}$ & $\begin{array}{l}\text { Synchronous, asynchronous, } \\
\text { private and shared } \\
\text { communication. }\end{array}$ \\
\hline $\begin{array}{l}\text { Professional } \\
\text { update and } \\
\text { learning among } \\
\text { equals }\end{array}$ & $\begin{array}{l}\text { - Thesaurus } \\
\text { - Documentaries }\end{array}$ & $\begin{array}{l}\text { Use of the resources, comments } \\
\text { about resources, chance to } \\
\text { increase materials, recommen- } \\
\text { dation and sharing of good } \\
\text { practices }\end{array}$ \\
\hline
\end{tabular}

different typology: from the informal exchanges on the shared wall, to the e-learning area, to the community up to the trading. The operations that Sonetto offers are profound and branched. The communication, learning and advertisement processes of the touristic supply can be realized on different levels, depending on the user's need; the activities based on three levels-communication, learning and promotion-can be transversal and contextual.

\section{The Interactive Resources: From Socialization to Gamification}

The resources created for Sonetto have been realized focusing on multimedia languages typical of the digital textuality: interactive presentations, documentaries and video games embrace all kind of semiotic codes. The diversification of the didactic forms of narration creates micro-stories to better fulfil the narration's goals and also to better customize the personal use of the environment.

Embracing the claim of deMarcos, Dominques, Saenz de Navarrete, and Pages (2014), the potentiality of networking is linked with gamification dynamics to associate "long-term motivational benefits of gamification '...' with the collaborative and participative capabilities offered by social networks" (p. 91). In a study about the use of blogs and social networks by adults and the informal learning processes correlated to them, Heo and Lee (2013) confirm that

"Web 2.0 as an informal learning environment enables adult learners to engage in different levels of interaction and participation in social activities and hence to experience diverse dimensions of learning depending on their own purposes as self-regulated and self-directed learners" (p. 143).

Because of that is necessary identify "learning objectives, but also roles and degrees of engagement, in order to plan learning processes and outcomes" (Heo \& Lee, 2013, p.143). The gamification action can increase the commitment level, can diversify the didactic-content's use and start a self-confident dynamics. Three functional areas, corresponding to specific resources and possible activities for users, can be identified on the environment's structure (Table 2).

The following is a screenshot of the Sonetto environment, showing the home page of the website (Figs. 1 and 2). 


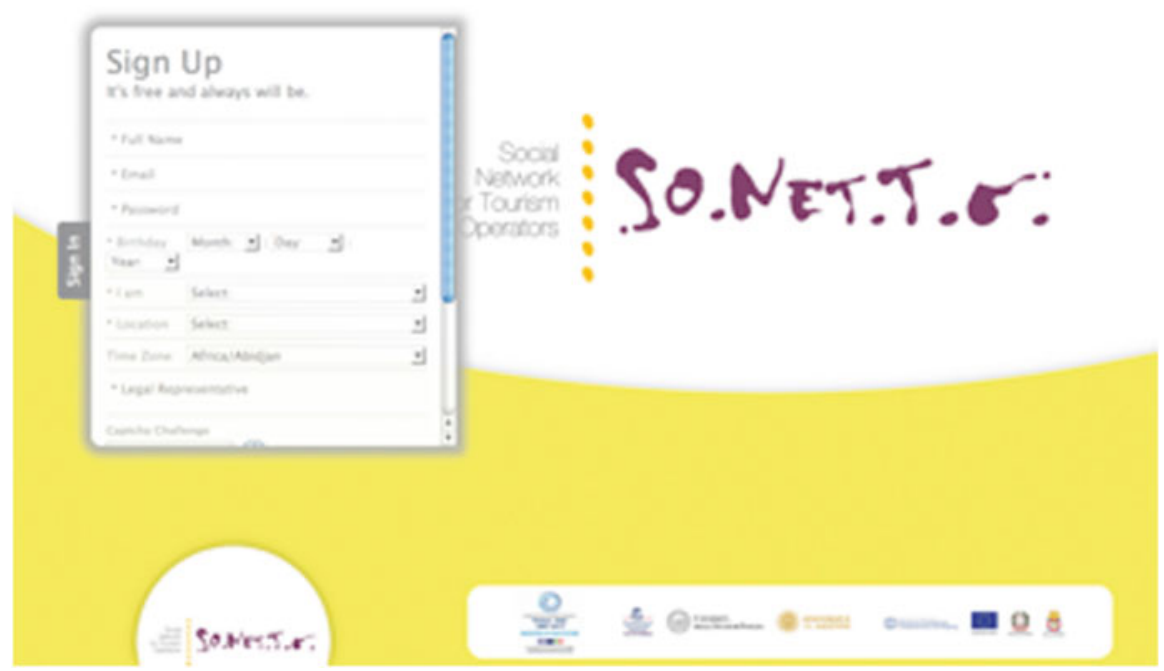

Fig. 1 Homepage of the portal Sonetto

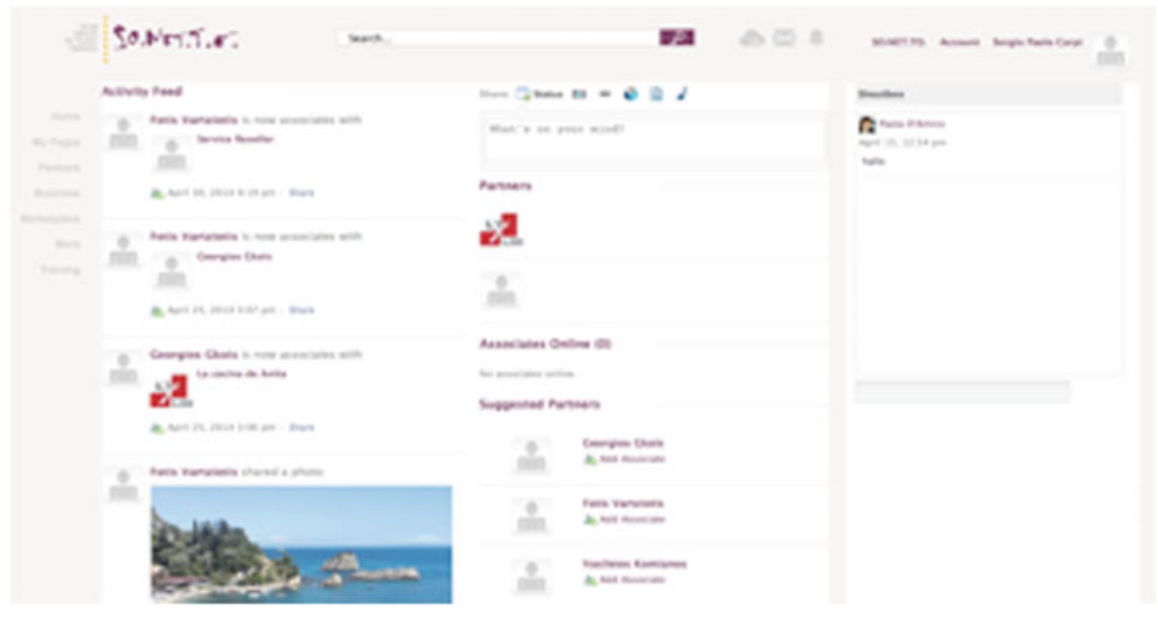

Fig. 2 Community of the portal Sonetto

\section{The Gamification Actions in the Sonetto Community}

The gamification actions designed within the community of Sonetto had as main goal the activation of informal processes based on peer education in which the sharing process is not restricted to information, but embrace knowledge and experiences of all professionals that join the community. The Sonetto's community configures itself as a collaborative on-line environment that tries to support the 
voluntary informal learning, and non-voluntary too, through several forms of participation.

A vast scientific literature (Buckingham, 2013; Gee, 2007; Ito, 2009) shows how video games have passed the obsolete idea of being targeted only for teenagers and with the only purpose of amusement, often also with no contempt for violence. A further evidence of this social-cultural innovation is that always more frequently both private enterprises and public authority are using video games in their communication strategies. After the big success of Foursquare, a social-network that permits the geographic-localization through mobile disposal, it is clearly proved that the gaming is very efficient in producing positive behaviour in people of all age (Deterding, Dixon, Khaled, \& Nacke, 2011). Gamification is referred to the use of video games in the every-day life and more precisely within not gaming playful dynamics.

The term has been proposed in 2008 in a post within the Brett Terill's blog as Gamification to describe the use of game-techniques on the web to increase the user's engagement. In 2010, the term has been incorporated in the industrial context changing in "Gamification" (Huotari \& Hamari, 2012). In the academic environment, Jesse Schell, an American scholar and famous game designer, has used the term Gamification for the first time in February 2010 in Las Vegas during the Dice Conference 2010. There are several definitions of Gamification. In a very marketing oriented perspective, Kai Huotari and Juho Hamari (2012) define it as "a process of enhancing a service with affordances for gameful experiences in order to support user's overall value creation". Consequently, they argue that the definition of gamification cannot be based on a set of methods or mechanics, but instead it has to be recognized as a process in which the gamifier is challenging to amplify the likelihood for the gameful experiences to emerge by imbuing the service with affordances for that purpose. The term affordance, in this case, refers to any qualities of the service system that contributes to the emergence of gameful experience. The term Gamification is strongly contested, in particular in video game sector and by the scientific community that works on game studies: they contest the simplification and the free interpretations of the term. The well-know scholar and game designer Jane McGonigal (2011) and the scholar Ian Bogost (2011) suggest to substitute gamification with "exploitation ware" because it can better represent the "villainous reign of abuse" which is involved in gamification systems. Moreover, it is important for some scholars to find a term without game within, because of the different fields of applications that they can relate to.

The gamification systems are based on four main ideas that are represented by points, levels, prizes, goals that add something new to the everyday life without providing any rewards. A clear example could be represented by a student who receives a reward for his good performance in school or there could be a system of scores and levels for good conduct. Therefore, the use of the gamification could change the user's behaviour bringing him from a personal sphere of interest (A) to a business one (B). Between A and B it is then possible to create a strong engagement and a relationship based on loyalty that makes the interaction between the two parts less boring and more attractive. According with Gabe Zichermann (2014), 
Marketing managers always follow the latest trend and understand that if they aren't learning about important developments, such as gamification, then they are falling behind the competition. Smart marketers understand gamification works best when it is executed well, whether it is a full-fledged gamified experience or the insertion of a few game mechanics to help onboard or engage. In either case, gamification can't just be a simple task-reward process; it needs to be immersive and engaging in order to produce results.

In the case of Foursquare, the users, checking in some places, receive "badges", a sort of reward for some goals achieved in particular places, frequencies etc. The base mechanics, which can be integrated, are points, levels, virtual goods, virtual currencies, badges, leaderboard and gifts. On this main structure it is possible to build further game mechanics which are referred to a prearranged consumer's behaviour. An essential part for a good application is the community. People like to share their own feelings, successes and to publish the results of the challenges on the social media.

The video games realized for the project configure themselves as on-line playfuldidactic itinerary of interactive nature; through the definition of levels and always more difficult game-action, they give information about several aspects of the luxury and eco-friendly tourism: landscapes, food, niche tourism, etc.

The writings, pictures and hypertext references within the digital texts, allow to read in depth themes and concepts while playing. The didactic goals linked with the playful-didactic products are:

- To know the niche territorial resources and value them in a touristic perspective;

- To examine the socioeconomic bases in term of touristic success;

- To think the professional practice in playful terms.

It follows a synthetic presentation of the five games realized (Table 3):

Table 3 The Sonetto games

\begin{tabular}{|c|c|}
\hline Name and description & Focus \\
\hline \multicolumn{2}{|l|}{ Cross Sonetto } \\
\hline $\begin{array}{l}\text { Crossword on two level (easy, hard) about the } \\
\text { main touristic attractions of Apulia }\end{array}$ & $\begin{array}{l}\text { Linguistic: identification of names and defi- } \\
\text { nitions of the most typical products of } \\
\text { Apulia }\end{array}$ \\
\hline \multicolumn{2}{|l|}{ Quiz Sonetto } \\
\hline $\begin{array}{l}\text { Quiz on four levels, time restriction. It presents } \\
\text { the wine and food resources and the cultural } \\
\text { tradition resources. }\end{array}$ & $\begin{array}{l}\text { Visual-linguistic: graphical and nominal } \\
\text { presentation of some of the territorial } \\
\text { resources }\end{array}$ \\
\hline \multicolumn{2}{|l|}{ Find your place } \\
\hline $\begin{array}{l}\text { Interactive guide to locate the best place to visit } \\
\text { according to the personal needs }\end{array}$ & Spatial: localized choice of places and paths \\
\hline \multicolumn{2}{|l|}{ Sonetto nature } \\
\hline $\begin{array}{l}\text { Game that allow to discover the landscape of } \\
\text { Apulia through pictures of three natural areas: } \\
\text { Area Marina di Torre Guaceto, Parco Nazionale } \\
\text { del Gargano, Parco Nazionale dell'Alta Murgia }\end{array}$ & $\begin{array}{l}\text { Visual-linguistic: discovery of the natural } \\
\text { beauties of the landscape }\end{array}$ \\
\hline
\end{tabular}

Puzzle Sonetto

A graphic composition of places and towns to discover the history and the art of Apulia 


\section{Find Your Place}
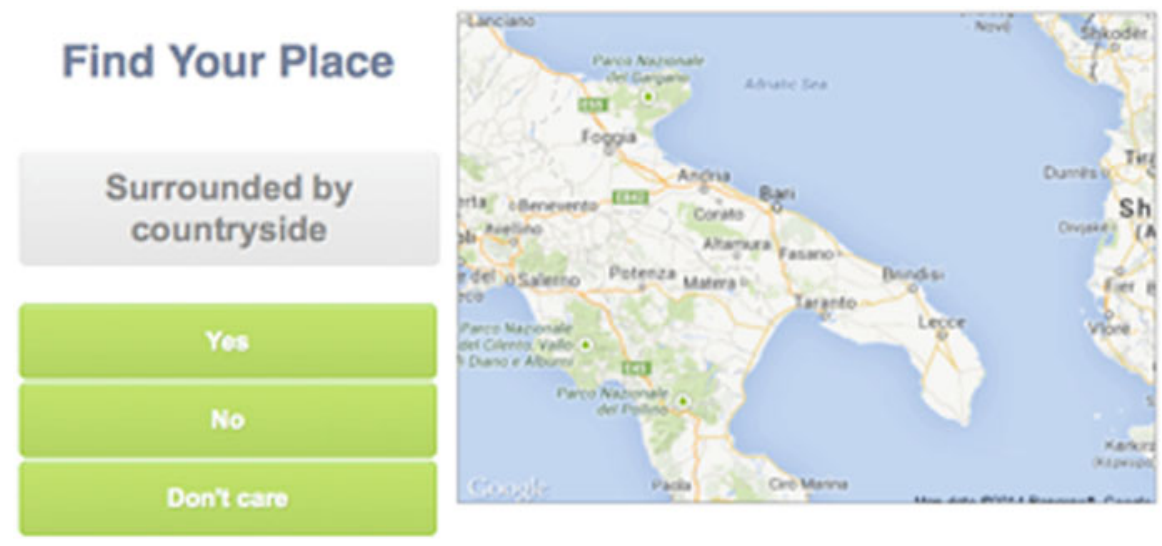

Fig. 3 Find your place

The following (Figs. 3, 4, 5, 6, and 7) are some screenshots taken from the games above described:

The gamification activities included on Sonetto platform are fully connected to the community. Gamification has recently evolved as an approach to engage and encourage active participation of members in online communities. For an online community to start and proceed on to a sustainable operation, it is important that members are encouraged to contribute positively and frequently (Bista, Nepal, Colineau, \& Paris, 2012). And it is the main goal and result of the platform.

\section{Further Directions}

Starting from the research of Michael Eraut (2004), who defines the "factors affecting learning in the workplace", John Cook and Norbert Pachler (2012) added a "typology of factors in social (mobile) network(ing) services and workbased learning" (p. 718). These literature references suggested an original selection of factors that can help us to describe the Sonetto activities (Table 4).

Sonetto represents one of the steps of a long-lasting ERID $\mathrm{Lab}^{2}$ research related to the digital learning environments for education and training. As further perspective, the monitoring of the users' experience will also be developed, in order to detect their satisfaction and perceived learning. The processes and potentialities of gamification will also be analyzed with a theoretical and applied approach.

\footnotetext{
${ }^{2}$ ERID Lab is the laboratory for "Educational Research and Interaction Design" of the University of Foggia-Department of Humanities-with specific skills in educational research and interaction design. The interdisciplinary research group works for the implementation of prototypes and educational design solutions, mainly for school settings, museums, and training settings and investigates social learning processes, participatory design experiences and e-learning paths.
} 


\section{QuizSONETTO}

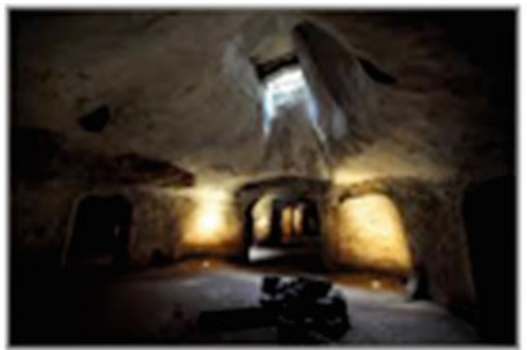

The 'trappeti', oil mills placed in the rocks, are the typical structures of;

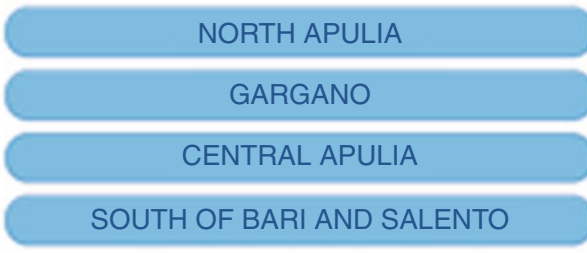

Choose the right answer!

Fig. 4 Quiz Sonetto

\section{So.NrT. : Nature - National Park of Gargano}

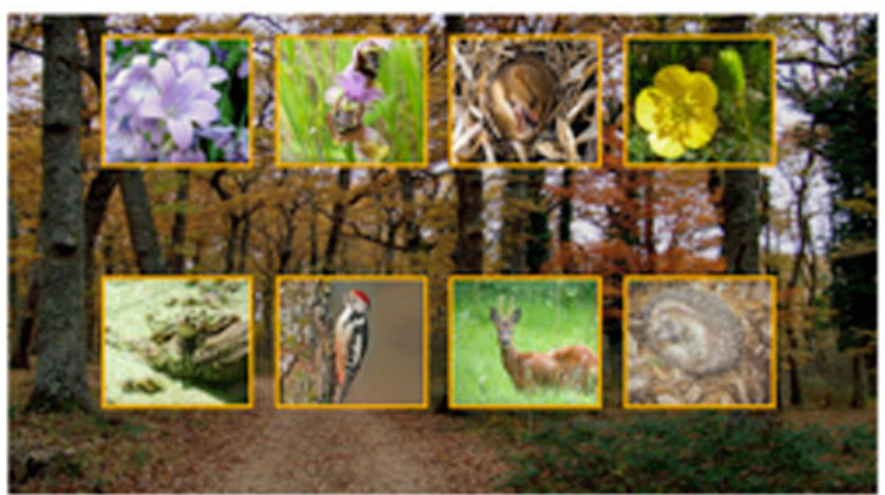

Right Answert!

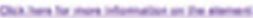

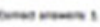

sment.

The next element to find is:

RowDeer

Fig. 5 Sonetto Nature 


\section{Cross SO.NeT.T.E:}

\section{Difficult Level}

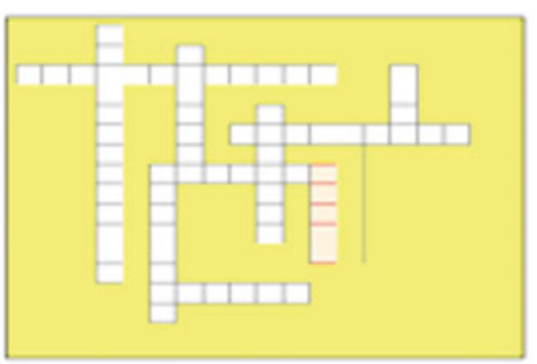

Bolve Came

Ge Besk

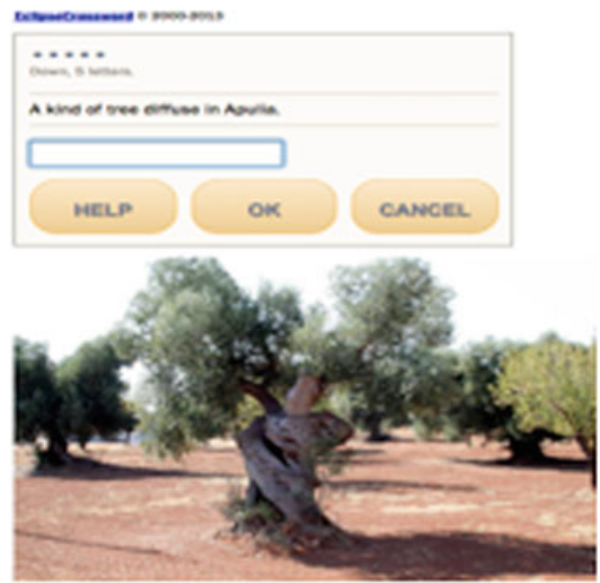

Fig. 6 Cross So.Net.T.O
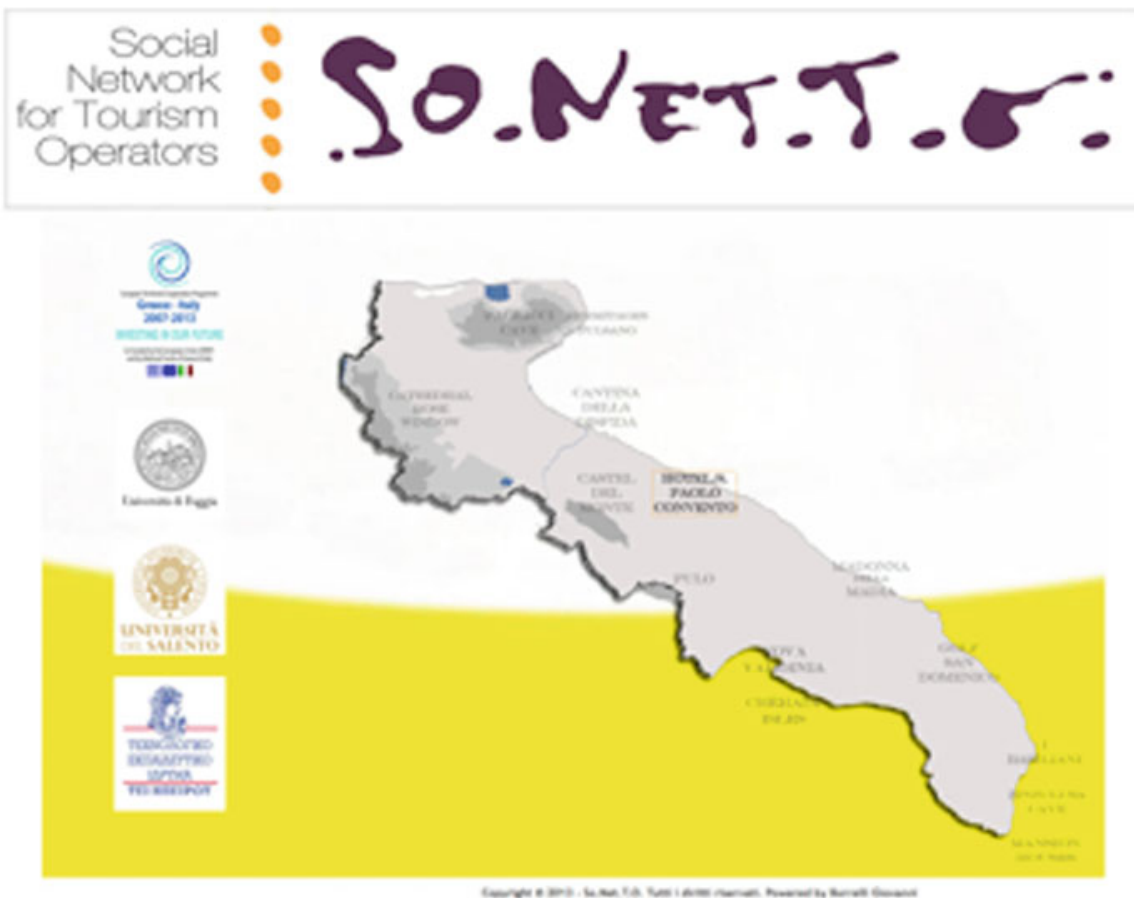

Fig. 7 Puzzle So.Net.T.O 
Table 4 Factors affecting learning in Sonetto platform

Context factors

a. Crossborder and inter-sector connections

b. Online relationship among operators Multi-purpose tools and spaces: communication, learning, marketing aims

They are processes linked with the context where the learning takes place and where project actions develop with the support of the digital environment. The international and intersectorial connections, the relationships among operators for communicative, didactic and commercial activities better define the scenario where the didactic process takes place.

Learning factors

a. Individual self-efficacy

b. Acts of self-regulation within and outside the environment

c. Multiliteracy (reading and writing the complex texts of digital environments)

d. Personal learning networks

Actions and processes linked to the didactic activity where personal, relational ad cognitive dynamics are involved: peer and digital environment feedbacks, relationships in the web community, creation and maintaining of connections, etc.

\section{Digital environment factors}

a. Accessible resources and environment

b. Linguistic effectiveness of multimedia and multimodal materials

c. Affordances of the system in relation to the communicative, educational and commercial aspect

Such aspects refer to the platform design and to its features as well as the quality of the proposed multimedia materials. These elements influence the activity within the environment as well as the interaction among the users.

Finally, it seems necessary to increase the research activity that can link scientific research, industrial development and local actors, as suggested by the $E U$ Framework Programme for Research and Innovation, Horizon 2020. In particular, this synergic action could link the knowledge driven research with the technology driven innovation, up to the society driven industrial and commercial applications (Ricerca 2013, p. 27; Limone, 2014). This is one of the possible strategies to realize a social innovation that, with the support of the digital technology, could detect and answer the needs of a changing and challenging economic and cultural scenario.

\section{References}

Baert, H., De Witte, K., \& Sterck, G. (2000). Vorming, training en opleiding. Handboek voor een kwaliteitsvol VTO-beleid in welzijnsvoorzieningen, (Instruction, Training and Education (ITE)). Handbook for a High Quality ITE-policy in Welfare Services). Leuven: Garant.

Bista, S. K., Nepal, S., Colineau, N., \& Paris, C. (2012). Using gamification in an online community. Collaborative Computing: Networking, Applications and Worksharing (CollaborateCom), 2012 8th International Conference on. IEEE, 2012.

Bogost, I. (2011). Gamification is bullshit. The Atlantic: Technology. Retrived from http://www. theatlantic.com/technology/archive/2011/08/gamification-is-bullshit/243338/. Accessed the 25th of January 2014, at 14:50.

Bonaiuti, C. (2006). E-Learning 2.0. Il futuro dell'apprendimento in rete, tra formale e informale. I quadernidiForm@re n.6. Trento: Edizioni Erickson. 
Boyd, D., \& Ellison, N. B. (2008). Social network sites: Definition, history and scholarship. Journal of Computer-Mediated Communication, 13, 210-230.

Buckingham, D. (2013). Beyond technology: Children's learning in the age of digital culture. London: John Wiley \& Sons.

Cook, J., \& Pachler, N. (2012). Online people tagging: social (mobile) network(ing) services and work-based learning. British Journal of Educational Technology, 43(5), 711-725.

Cross, J. (2007). Informal learning. Rediscovering the natural pathways that inspire innovation and performance. San Francisco: Wiley.

deMarcos, L., Dominques, A., Saenz de Navarrete, J., \& Pages, C. (2014). An empirical study comparing gamification and social networking on e-learning. Computers \& Education, 75, 82-91.

Deterding, S., Dixon, D., Khaled, R., \& Nacke, L. (2011, September). From game design elements to gamefulness: Defining gamification. Proceedings of the 15th International Academic MindTrek Conference: Envisioning Future Media Environments. ACM (pp. 9-15).

Eraut, M. (1994). Developing professional knowledge and competence. London: Farmer Press.

Eraut, M. (2004). Informal learning in the workplace. Studies in Continuing Education, 26(2), $247-273$.

European Commission. (2005). Working together for growth and jobs. A new start for the Lisbon strategy. COM (2005) 24. Retrieved from http://eur-lex.europa.eu/LexUriServ/site/en/com/ 2005/com2005_0024en01.pdf. Accessed the 16 th of November 2013, at 14:00.

European Commission. (2009). Council conclusions on a strategic framework for European cooperation in education and training (ET 2020). Retrieved from http://www.cnsiium.eurpa. eu/uedcs/cms-data/dcs/pressdata/en/educ/107622.pdf2009-05-12/2010-05-02. Accessed the 16 th of November 2013, at 18:00

Gee, J. P. (2004). Learning by design: Games as learning machines. Interactive Educational Multimedia, 8, 15-23.

Gee, J. P. (2007). What video games have to teach us about learning and literacy. Revised and Updated Edition. New York: Macmillan.

Gray, C., \& Smyth, K. (2012). Collaboration creation: Lessons learned from establishing an online professional learning community. The Electronic Journal of e-Learning, 10(1), 60-75.

Greenfield, P. M. (2004). Developmental considerations for determining appropriate Internet use guidelines for children and adolescents. Applied Developmental Psychology, 25, 751-762.

Heo, G. M., \& Lee, R. (2013). Blogs and social network sites as activity systems: Exploring adult informal learning process through activity theory framework. Educational Technology \& Society, 16(4), 133-145.

Huotari, K., \& Hamari, J. (2012). Defining gamification: A service marketing perspective. Proceeding of the 16th International Academic MindTrek Conference (pp. 17-22), ACM.

Ito, M. (2009). Sociocultural contexts of game-based learning. Committee on Learning Science: Computer Games, Simulations, and Education. Retrieved from http://www.itofisher.com/mito/ publications/sociocultural_c.html. Accessed the 12 th of December 2013, at 20.30

Ito, M., Gutiérrez, K., Livingstone, S., Penuel, B., Rhodes, J., Salen, K., et al. (2013). Connected learning: An agenda for research and design. Digital Media and Learning Research Hub. Retrieved from http://dmlhub.net/sites/default/files/ConnectedLearning_report.pdf. Accessed the 12 th of December 2013, at 20.00

Kelle, S., Sigurðarson, S. E., Westera, W., \& Specht, M. (2011). Game based lifelong learning. E-Infrastructures and technologies for lifelong learning: Next generation environments. p. 337.

Kyndt, E., Dochy, F., \& Nijs, H. (2009). Learning conditions for non-formal and informal workplace learning. Journal of Workplace Learning, 21(5), 369-383.

Limone, P. (2014). Il design dell'ambiente di apprendimento SONETTO e la progettazione delle risorse didattiche. In I. Loiodice (Ed.), Turismo culturale sostenibile e formazione degli operatori turistici (pp. 83-97). 
Marconi, A. (Ed.). (2008). Il cantiere delle competenze. Formazione e lavoro nella società della conoscenza. Roma: Armando Editore.

McGonigal, J. (2011). Reality is broken: Why games make us better and how they can change the world. New York: The Penguin Press.

Merchant, G. (2012). Unravelling the social network: Theory and research. Learning, Media and Technology, 37(1), 4-19.

Ministero dell'Istruzione dell'Università e della Ricerca (2013). HORIZON 2020 Italia. From https://www.researchitaly.it/uploads/50/HIT2020.pdf

Rogoff, B. (2003). The cultural nature of human development. New York: Oxford University Press.

Scribner, S., \& Cole, M. (1973). Cognitive consequences of formal and informal education: New accommodations are needed between school-based learning and learning experiences of everyday life. Science, 182(4112), 553-559.

Squire, K. D. (2008). Video game-based learning: An emerging paradigm for instruction. Performance Improvement Quarterly, 21(2), 7-36.

Squire, K., \& Patterson, N. (2010). Games and simulations in informal science education (Learning science: Computer games, simulations, and education). Washington, DC: National Research Council.

Thompson, D., Baranowski, T., Buday, R., Baranowski, J., Thompson, V., Jago, R., et al. (2010). Serious video games for health: How behavioral science guided the development of a serious video game. Simulation \& gaming, 41(4), 587-606.

Zichermann, G. (2014), Gamification: 8 Tips for making it work. Retrieved from http://www. businessnewsdaily.com/6151-gamifying-best-practices.html. Accessed the 12 th of December 2013 , at 20.30 